\title{
THE INFLUENCE OF END-STAGE LIVER DISEASE AND LIVER TRANSPLANTATION ON THYROID HORMONES
}

\author{
Karla Rocha PENTEAD0 ${ }^{1}$, Júlio Cezar Uili COELHO², Mônica Beatriz PAROLIN², \\ Jorge Eduardo Fouto MATIAS² and Alexandre Coutinho Teixeira de FREITAS ${ }^{2}$
}

\begin{abstract}
Background - Thyroid dysfunction has been reported in most chronic illnesses including severe liver disease. These defects in thyroid hormone metabolism result in the sick euthyroid syndrome, also known as low T3 syndrome. Objectives - Our objective was to evaluate the thyroid function in patients with end stage liver disease prior and after deceased donor liver transplantation and to correlate thyroid hormonal changes with the MELD score (Model for End stage Liver Disease). Methods - In a prospective study, serum levels of thyrotropin (thyroid stimulating hormone - TSH), total thyroxine (tT4), free thyroxine (fT4) and triiodothyronine (T3) from 30 male adult patients with end stage liver disease were measured two to four hours before and 6 months after liver transplantation (LT). MELD was determined on the day of transplant. For this analysis, extra points were not added for patients with hepatocellular carcinoma. Results - The patients had normal TSH and fT4 levels before LT and there was no change after the procedure. Total thyroxine and triiodothyronine were within the normal range before LT, except for four patients $(13.3 \%)$ whose values were lower. Both hormones increased to normal values in all four patients after LT $(P=0.02$ and $P<0.001$, respectively). When the patients were divided into two groups (MELD $<18$ and MELD $\geq 18$ ), it was observed that there was no change in the TSH, freeT4, and total T4 levels in both groups after LT. Although there was no significant variation in the level of T3 in MELD $<18$ group $(P=0.055)$, there was an increase in the MELD $\geq 18$ group after LT $(P=0.003)$. Conclusion - Patients with end stage liver disease subjected to liver transplantation had normal TSH and fT4 levels before and after LT. In a few patients with lower tT4 and T3 levels before LT, the level of these hormones increased to normal after LT.
\end{abstract}

HEADINGS - Liver transplantation. Thyrotropin. Thyroxine. Triiodothyronine. Liver cirrhosis. End stage liver disease. Euthyroid sick syndromes.

\section{INTRODUCTION}

Thyroid hormones are essential for normal basal metabolic rate regulation of all cells, including hepatocytes ${ }^{(1,9,10)}$. The liver plays an important role in maintaining thyroid hormone homeostasis. It synthesizes and secretes the thyroid hormone-binding proteins and it is the principal organ responsible for the conversion of thyroxine (T4) to triiodothyronine (T3), accounting for $80 \%$ of the T3 produced daily from $\mathrm{T} 4^{(1,6,8,9,19)}$. $\mathrm{T} 4$ is a prohormone and the main secretory product of the thyroid and $\mathrm{T} 3$ is the biologically active form of thyroid hormone.

Thyroid dysfunction has been reported in several chronic diseases, including in end stage liver disease $(\text { ESLD })^{(3,9,10,15)}$. These thyroid hormone metabolism changes result in the sick euthyroid syndrome, also known as low T3 syndrome. This is characterized by reduction of extra-thyroidal T4-to-T3 conversion and, consequently, a low total T3, low free T3, an elevated rT3 (reverse T3), normal/low total T4 and normal/ high free $\mathrm{T} 4^{(1,4,8-10,15,19)}$.

The relationship between ESLD and thyroid hormones remains controversial. Some studies have demonstrated an inverse correlation between serum T3 concentrations and the severity of liver dysfunction $^{(1,7,9,10,15,17)}$. However, most patients with ESLD are euthyroid and have no clinical signs of hypothyroidism $^{(9,19)}$. Thyroid function has been evaluated as a marker of prognosis of liver disease and the thyroid function abnormalities usually are reversed following liver function improvement ${ }^{(10,15,16)}$. The correlation between the thyroid hormonal changes and the MELD score has not been evaluated yet. In the present study, the influence of ESLD and liver transplantation (LT) in thyroid function and peripheral hormone levels was evaluated prior and after LT. The correlation between thyroid hormone levels and the MELD score was also assessed.

Declared conflict of interest of all authors: none

Disclosure of funding: no funding received

Serviço de Transplante Hepático do Hospital de Clínicas, Universidade Federal do Paraná (UFPR); ${ }^{2}$ Departamento de Cirurgia do Aparelho Digestivo, UFPR. Curitiba, PR, Brasil.

Correspondence: Prof. Júlio Cezar Uili Coelho. Rua Bento Viana, 1140, ap. 2202. CEP: 80240-110 - Curitiba, PR. Brasil. Email: coelhojcu@yahoo.com.br 


\section{METHODS}

\section{Subjects}

The protocol of this study was approved by the Research Committee of the University Hospital of the Federal University of Paraná, Brazil and conformed to the ethical guidelines of the 1975 Helsinki declaration. All patients provided informed consent to participate in the study.

In the period between August 2008 to January 2011, 93 patients underwent LT and were all prospectively selected to participate in the study. Patients subjected to living donor liver transplantation, re-transplantation, multiorgan transplantation, domino liver transplantation, split or reduced liver transplantation were excluded, as well, patients under 18 years of age, females and five patients who died before the study completion. We therefore analyzed a total of 30 patients, after excluding those mentioned above, in order to specifically study the male population, subjected to deceased donor liver transplantation. Exclusion of some group of patients limits the generalization of the findings of the study.

\section{Assays}

Peripheral venous blood samples were collected 2-4 hours prior to anesthesia induction for LT and 6 months after the transplantation for determination of serum level of thyroid-stimulating hormone (TSH), total thyroxine (tT4), free thyroxine (fT4) and triiodothyronine (T3) by specific radioimmunoassay. Serum samples were kept frozen at $-80^{\circ} \mathrm{C}$ to be assayed later. The patients did not receive any medication that might have affected thyroid hormone determination. Serum total bilirubin, pro-thrombin, and creatinine were measured by routine biochemical tests to determine the MELD score on the transplantation day.

After LT, all patients were placed on standard immunosuppressive protocol consisting of tacrolimus or cyclosporine, mycophenolate mofetil and corticosteroids.

\section{Statistical analysis}

All data were obtained by the investigator and entered into a spreadsheet (Microsoft Excel ${ }^{\circledR}$ ), and later exported for further statistical analysis (Statistica - Statsoft ${ }^{\circledR}$ ).

Values were expressed as average and standard deviation (average $\pm \mathrm{SD}$ ) for continuous variables symmetrically distributed and as median, minimum and maximum values for the asymmetric distribution. The estimate of the difference of continuous variables with normal distribution was performed by parametric Student $t$ test for dependent samples and Anova for repeated measures. Nonparametric tests Wilcoxon and Friedman Anova were used for asymmetric distribution of variables. The MacNemar test was applied to study the behavior of hormonal and biochemical variables according to reference values, evaluating changes in categories: normal, below and above the reference value, before and after liver transplantation. Results were considered statistically significant when $P \leq 0.05$.

\section{RESULTS}

Epidemiological and clinical features of the patients are shown in Table 1 . The age of the patients varies from 25 to 64 years, with a mean of 51.4 years. Etiology of liver disease varied widely. The most common causes were chronic hepatitis C virus infection (30\%) and alcohol (26.7\%). All patients with alcoholic cirrhosis had abstained from alcohol for at least 6 months prior to LT. Child-Pugh classification and MELD score were used to determine the severity of the liver disease. MELD ranged from 10 to 30 points, with an average of $17.7 \pm 4.2(95 \% \mathrm{CI}=16.1-19.2)$. For this purpose, additional points were not added to the MELD score of patients with associated hepatocellular carcinoma.

The serum values of TSH, tT4, fT4 and T3 before and 6 months after liver transplantation are shown in Table 2. Almost all patients had normal TSH $(96.5 \%)$ and fT4 (100\%) levels before LT (control values: $0.3-5.0 \mathrm{mcUI} / \mathrm{mL}$ and 0.8 $1.9 \mathrm{ng} / \mathrm{dL}$, respectively) and there was no change after LT

TABLE 1. Epidemiological and clinical characteristics of the patients

\begin{tabular}{lc}
\hline Characteristics & Patients \\
\hline Number & 30 \\
Age (year) & $51.4 \pm 7.6$ \\
Mean \pm SD & $25-64$ \\
Range & 48.6 to 54.3 \\
$95 \%$ CI & $30 / 0$ \\
Gender (male/female) & $\mathrm{N}(\%)$ \\
Etiology of Cirrhosis & $9(30.0)$ \\
Chronic HCV infection & $8(26.7)$ \\
Ethanol chronic abuse & $3(10.0)$ \\
NASH & $2(6.7)$ \\
Chronic HBV infection & $2(6.7)$ \\
Hemochromatosis & $6(20.0)$ \\
Others & $4(13.33)$ \\
Hepatocellular Carcinoma Associated & \\
Child-Pugh Classification & $4(13.3)$ \\
A & $10(33.3)$ \\
B & $16(53.4)$ \\
C & \\
MELD Score & $17(56.7)$ \\
10-17 & $11(36.7)$ \\
18-22 & $2(6.7)$ \\
>23
\end{tabular}

CI: confidence interval; HCV: hepatitis C virus; HBV: hepatitis B virus; NASH: non-alcoholic steatohepatitis

TABLE 2. Serum levels of TSH, Free T4, Total T4, and T3

\begin{tabular}{lcccc}
\hline Hormone & Reference Value & Before LT & After LT & \multicolumn{1}{c}{} \\
\hline TSH & $0.3-5.0 \mathrm{mcUI} / \mathrm{mL}$ & $1.8(0.1-4.9)$ & $2.1(0.8-5.3)$ & $0.34^{* *}$ \\
Free T4 & $0.8-1.9 \mathrm{ng} / \mathrm{dL}$ & $1.1(0.9-1.5)$ & $1.2(0.8-2.0)$ & $0.43 * *$ \\
Total T4 & $4.5-12.5 \mathrm{mcg} / \mathrm{dL}$ & $6.9 \pm 2.2$ & $8.3 \pm 2.2$ & $0.02 *$ \\
T3 & $70-210 \mathrm{ng} / \mathrm{dL}$ & $81.9 \pm 19.5$ & $109.9 \pm 27.1$ & $<0.001 *$ \\
\hline
\end{tabular}

TSH: thyroid stimulating hormone; LT: liver transplantation; * $t$ Student test $/ * *$ Wilcoxon test 
( $P=1.00$ and $P=0.96$, respectively). The average values before and after transplantation were $1.8 \mathrm{mcUI} / \mathrm{mL}(0.1-4.9)$ and $2.1 \mathrm{mcUI} / \mathrm{mL}(0.8-5.3)$ for TSH and $1.1 \mathrm{ng} / \mathrm{dL}(0.9-1.5)$ and $1.2 \mathrm{ng} / \mathrm{dL}(0.8-2.0)$ for fT4.

Total thyroxine and triiodothyronine (control values: 4.5 $12.5 \mathrm{mcg} / \mathrm{dL}$ and $70-210 \mathrm{ng} / \mathrm{dL}$, respectively) were normal before and after LT (tT4 was $6.9 \pm 2.2 \mathrm{mcg} / \mathrm{dL}$ and $8.3 \pm 2.2$ $\mathrm{mcg} / \mathrm{dL}$; T3 was $81.9 \pm 19.5$ and $109 \pm 27.1$ before and after LT respectively), except for four patients (13.3\%) with abnormal values. Both hormones increased to normal values in all four patients after LT ( $P=0.02$ and $P<0.001$, respectively).

In order to evaluate the influence of the severity of the end-stage liver disease on the variation of serum levels of these hormones, patients were divided into two groups, based on the MELD score (MELD $<18$ group and MELD $\geq 18$ group - the average MELD value in the study was 17.7).

Figure 1 illustrates serum level changes of TSH before and after LT according to the classification of MELD score.

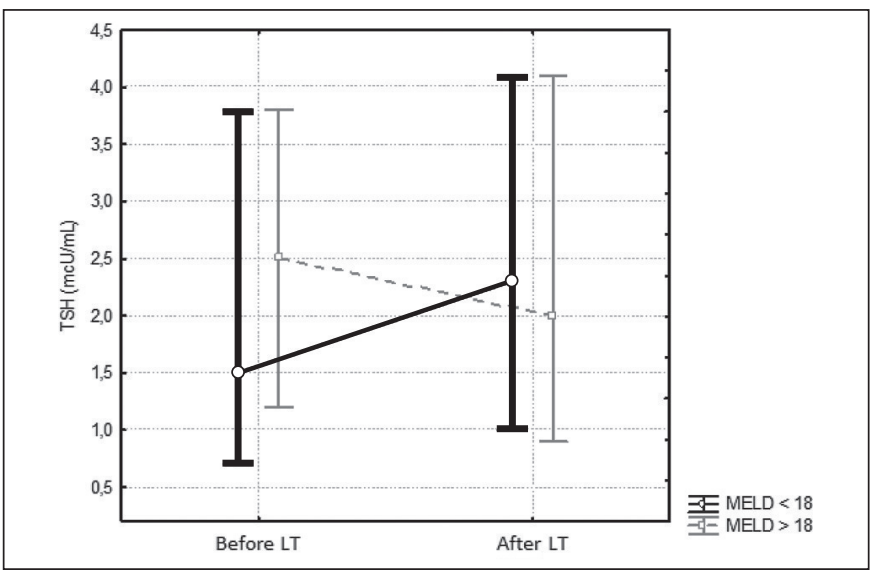

FIGURE 1. Evolution of Serum TSH according to the MELD Score. Liver transplantation (LT); thyroid-stimulating hormone (TSH). In both MELD $<18$ group $(P=0.11)$ and MELD $\geq 18$ group $(P=0.77)$, no statistically significant changes was observed.

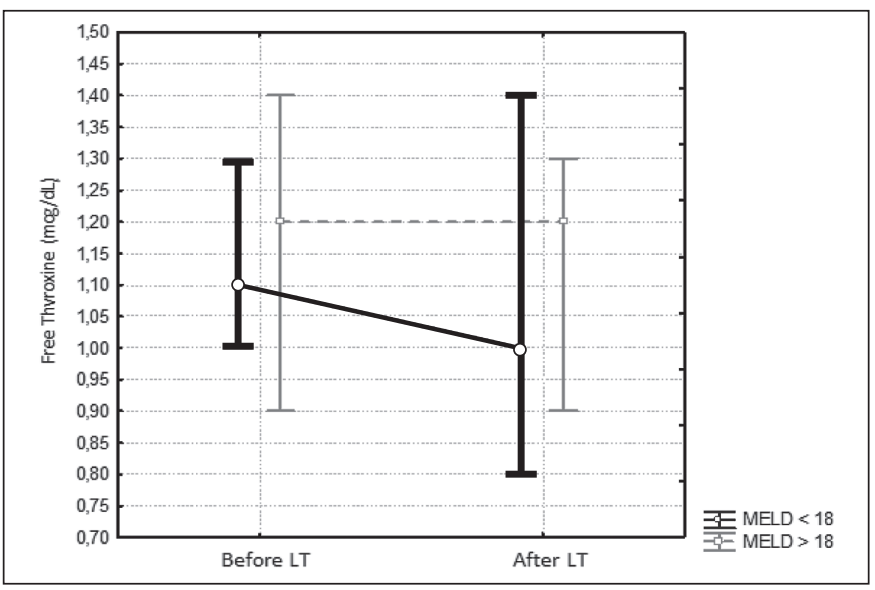

FIGURE 2. Evolution of Serum fT4 according to the MELD Score. Liver transplantation (LT); free thyroxine (fT 4 ). In both MELD $<18$ group $(P=0.80)$ and $\mathrm{MELD} \geq 18$ group $(P=0.77)$, no statistically significant changes was observed.
Both in the MELD $<18$ and in the MELD $\geq 18$ groups, there was no change in the TSH level after LT $(P=0.11$ and $P=0.44$, respectively).

Free T4 serum levels prior and after LT are illustrated in Figure 2. Both in the MELD $<18$ and in the MELD $\geq 18$ groups, there was no change in the level of fT4 after LT $(P=0.80$ and $P=0.77$, respectively). There was no significant difference in levels of fT4 between both groups in the pre $(P=0.78)$ and post-transplant $(P=0.42)$.

Total T4 level pre- and post-liver transplantation according to the MELD score is shown in Figure 3. In MELD $<18$ group, there was no significant variation in the amount of tT4 after LT $(P=0.63)$. In MELD $\geq 18$ group this measure was higher after LT $(P=0.003)$.

T3 levels prior and after LT are illustrated in Figure 4. Although there was no significant variation in the level of T3 in MELD $<18$ group $(P=0.055)$, there was an increase in the MELD $\geq 18$ group after LT $(P=0.003)$.

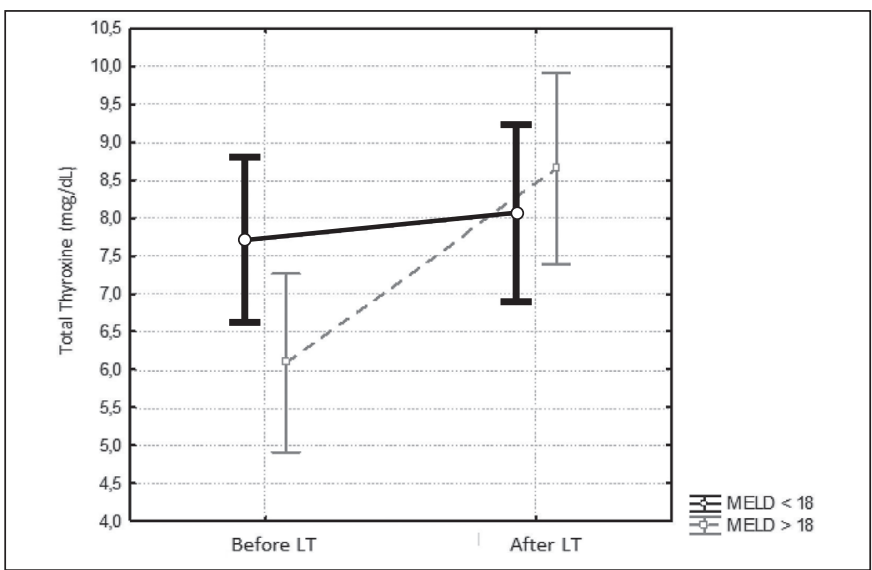

FIGURE 3. Evolution of Serum tT4 according to the MELD Score. Liver transplantation (LT); total thyroxine (tT4). In MELD <18 group, there was no change in the tT4 serum levels $(P=0.63)$. The values of tT4 increased in the MELD $\geq 18$ group $(P=0.003)$.

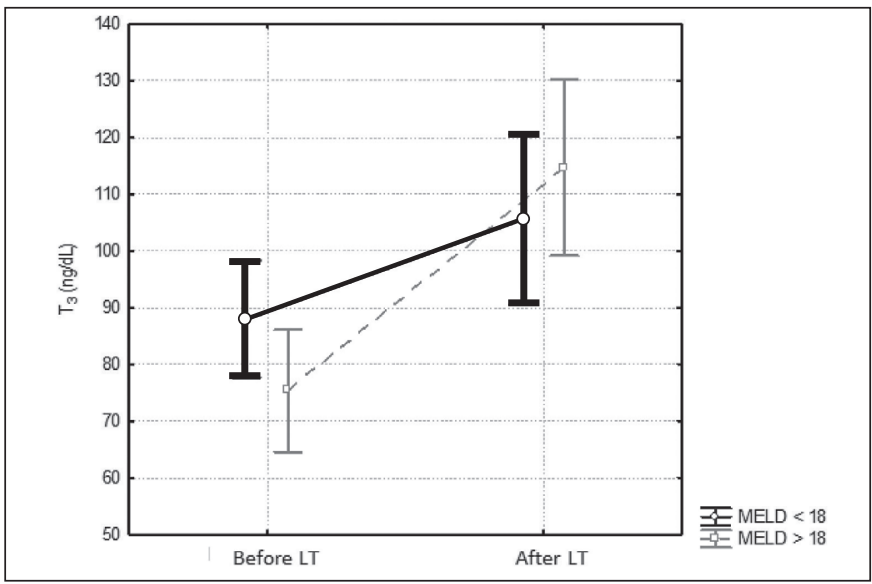

FIGURE 4. Evolution of Serum T3 according to the MELD Score. Liver transplantation (LT); triiodothyronine (T3). There was no significant variation in the level of T3 in MELD $<18$ group $(P=0.055)$, but there was an increase in the MELD $\geq 18$ group after LT $(P=0.003)$. 


\section{DISCUSSION}

The sick euthyroid syndrome, also known as low T3 syndrome, has been reported in several chronic diseases, including in chronic liver disease ${ }^{(1,4,8-11,15,19)}$. Since clinical signs of hipothyroidism develop only after prolonged period of thyroid hormone depletion, most cirrhotic patients remain asymptomatic ${ }^{(14)}$.

Low FT3 levels may be due to alterations of two main enzymes acting in the liver as part of the iodo-thyronine seleno-deiodinase enzyme system. The type 1 and type 3 deiodinases are responsible for extra- thyroidal production of T3 and inactivation of thyroid hormones, respectively. The decrease in total $\mathrm{T} 3$ is probably reflecting a reduced deiodinase type 1 activity, resulting in reduced conversion of T4 to T3 and an increase in conversion of T4 to reverse T3 by the deiodinase type 3 system in the liver of cirrhotic patient. Although, despite alteration in serum T3, serum TSH and T4 are reported to be steady, indicating adaptive mechanisms by which the body reduces basal metabolic rate and preserve the liver function ${ }^{(5,10)}$.

Some studies suggest that this syndrome may confer a survival advantage, which adapts an organism to chronic illness by reducing the basal metabolic rate within hepatocytes, reducing caloric requirements and preserving liver function and total body protein stores ${ }^{(5,10)}$ Bruck et al. showed in an experimental study on rats that subclinical hypothyroidism can be beneficial both in protecting the liver from further damage and in regression of established fibrosis in induced liver fibrosis ${ }^{(2)}$.

One important observation is the finding of low free T3. Consistently with literature data, we observed that in the group with more severe liver disease (MELD $\geq 18$ group), the values of T3 before LT were below the reference value in some patients. T3 increased to normal value after LT. In contrast, no significant changes were observed in the values of TSH and free T4. These findings are consistent with other studies that suggested that T3 serum levels correlate inversely with the severity of liver dysfunction ${ }^{(1,7,9,10,15,17)}$. Shakoor et al. have shown that the free T3 level is low in a cohort of 50 cirrhotic patients. These authors have also reported an inverse relationship between free T3 level and the severity of liver dysfunction ${ }^{(15)}$. Similarly, Borzio et al. who studied 55 patients of chronic hepatitis found low free T3 levels despite the presence of clinical euthyroidism ${ }^{(1)}$.

Some studies have shown that controlled subclinical hypothyroidism might be beneficial for euthyroid cirrhotic patients by protecting the liver from further damage. These studies, therefore, could be suggestive of a protective mechanism in which lower circulating T3 contributes to protect the liver from further fibrosis and helps the liver to reverse the damages ${ }^{(2,12)}$.

When evaluating the impact of liver transplantation on the thyroid function and on the peripheral hormone levels, we found complete normalization of T3 following liver transplantation in the four patients with low levels. Other authors reported similar finding ${ }^{(13,15,18)}$. Similarly to Seehofer et al. studied hormonal changed in 22 patients with chronic liver disease, who underwent LT. The patients have shown the already described "low T3 syndrome" and it completely resolved after $\mathrm{LT}^{(13)}$.

\section{CONCLUSION}

Patients with end-stage liver disease subjected to liver transplantation had normal TSH and fT4 levels before and after LT. In a few patients with lower tT4 and T3 levels before LT, the level of these hormones increased to normal after LT.

\section{Authors' contributions}

All authors contributed in the collection and analysis of data. The literature review and the development of the article were held by Penteado KR, with the assistance and revision of Coelho JCU.

Penteado KR, Coelho JCU, Parolin MB, Matias JEF, Freitas ACT. Avaliação do impacto da cirrose e do transplante hepático na função tireoidiana. Arq Gastroenterol. 2015,52(2):124-8.

RESUMO - Contexto - A disfunção tireoidiana tem sido relatada em associação com a maioria das doenças crônicas, incluindo a doença hepática terminal. Estes defeitos no metabolismo dos hormônios tireoidianos resultam na síndrome do doente eutireoideo ou, também conhecida como síndrome do T3 baixo. Objetivos - Avaliar a função tireoidiana em pacientes com doença hepática avançada, antes e depois de serem submetidos ao transplante hepático cadavérico (THC) e, correlacionar as alterações hormonais da tireóide com o MELD. Métodos - Em um estudo prospectivo, os níveis séricos de tireotropina (hormônio estimulante da tireóide - TSH), tiroxina total (T4 total), tiroxina livre (T4 livre) e triiodotironina (T3) de 30 pacientes adultos do sexo masculino com doença hepática terminal foram dosados 2 e 4 horas antes e 6 meses após o THC. O valor do MELD foi determinado no dia do procedimento. Para esta análise, os pontos extras não foram adicionados para os pacientes com carcinoma hepatocelular. Resultados - Os pacientes apresentaram níveis de TSH e T4 livre normais antes do THC e não houve nenhuma alteração após o procedimento. As dosagens de T4 total e T3 no início do estudo estavam dentro da faixa normal, exceto por quatro pacientes (13,3\%), os quais apresentavam valores abaixo da referência. Ambos os hormônios apresentaram um aumento 6 meses após o THC $(P=0,02$ e $P<0,001$, respectivamente). Quando os pacientes foram divididos em dois grupos (MELD <18 e MELD $\geq 18$ ) não observamos diferença nos níveis de TSH, T4 total e T4 livre entre os grupos após THC. Apesar de não haver variação nos níveis de T3 no grupo com MELD $<18(P=0,055)$, houve um aumento no grupo MELD $\geq 18$ após THC $(P=0,003)$. Conclusãa - Os pacientes com cirrose hepática submetidos a transplante hepático tinham valores normais de TSH e T4 livre antes e após o THC. Nos poucos pacientes que apresentavam valores baixos de T4 total e T3 antes do THC, houve normalização destes hormônios após o THC.

DESCRITORES - Transplante hepático. Tireotropina. Tiroxina. Tri-iodotironina. Cirrose hepática. Doença hepática terminal. Síndromes do eutireóideo doente. 


\section{REFERENCES}

1. Borzio M, Caldara R, Borzio F, Piepoli V, Rampini P, Ferrari C. Thyroid function tests in chronic liver disease: evidence for multiple abnormalities despite clinical euthyroidism. Gut. 1983;24(7):631-6.

2. Bruck R, Weiss S, Traister A, Zvibel I, Aeed H, Halpern Z, Oren R. Induced hypothyroidism accelerates the regression of liver fibrosis in rats. J Gastroenterol Hepatol. 2007;22(12):2189-94.

3. Chopra IJ, Solomon DH, Chopra U, Young RT, Chua Teco GN. Alterations in circulating thyroid hormones and thyrotropin in hepatic cirrhosis: evidence for euthyroidism despite subnormal serum triiodothyronine. J Clin Endocrinol Metab. 1974;39(3):501

4. El-Kabbany ZA, Hamza RT, Hakim ASA, Tawfik LM. Thyroid and Hepatic Haemodynamic Alterations among Egyptian Children with Liver Cirrhosis. ISRN Gastroenterol. 2012; 2012:595734. doi: 10.5402/2012/595734.

5. Ghanaei FM, Mehrdad M, Mortazavi S, Joukar F, Khak M, Atrkar-Roushan Z Decreased serum total T3 level in hepatitis B and C related cirrhosis by severity of liver damage. Annals of Hepatol. 2012;11(5): 667-71.

6. Green JRB, Snitcher EJ, Mowat NAG, Ekins RP, Rees LH, Dawson AM. Thyroid function and thyroid regulation in euthyroid men with chronic liver disease: evidence of multiple abnormalities. Clin Endocrinol (Oxf). 1977;7(6):453-61.

7. Javed R, Ghafoor F, Butt AK, Khan A. Significance of Total and Free Thyroid Hormones in relation to Serum Proteins in Chronic Hepatitis B patients and normal controls. Pakistan Journal of Medical Research. 2010;49(3):85-8.

8. Jennings AS, Ferguson DC, Utiger RD. Regulation of the Conversion of Thyroxine to Triiodothyronine in the Perfused Rat Liver. J Clin Invest. 1979;64(6):1614-23.

9. Kayacetina E, Kisakolb G, Kayab. Low serum total thyroxine and free triiodothyronine in patients with hepatic encephalopathy due to non-alcoholic cirrhosis. Swiss Med Weekly. 2003;133(13-14):210-3
10. Malik R, Hodgson $\mathrm{H}$. The relationship between the thyroid gland and the liver. QJM. 2002;95(9):559-69.

11. Moustafa AHA, Ali EMM, Mohamed TM, Abdou HI. Oxidative stress and thyroid hormones in patients with liver diseases. Eur J Intern Med. 2009;20(7):703-8.

12. Oren R, Sikuler E, Wong F, Blendis LM, Halpern Z. The effects of hypothyroidism on liver status of cirrhotic patients. J Clin Gastroenterol. 2000;31(2):162-3.

13. Seehofer D, Steinmueller T, Graef KJ, Rayes N, Wiegand W, Tullius SG, Settmacher U, Neuhaus P. Pituitary Function Test and Endocrine Status in Patient with Cirrhosis of the Liver before and after Hepatic Transplantation. Ann Transplant. 2002;7(2):32-7.

14. Setsuo N, Prrman CS, Chambers J, Buck MW, Shimzu T. Reduced Peripheral Conversion of Thyroxine to Triiodothyronine in Patients with Hepatic Cirrhosis. J Clin Invest. 1975;56(3):643-52.

15. Shakoor S, Kaneez FS, Iftikhar U. Free T3 as a Reliable Indicator of Thyroid Dysfunction in Cirrhosis. Iamure. 2012;1(1).

16. Silveira MG, Mendes FD, Diehl NN, Enders F, Lindor KD. Thyroid dysfunction in primary biliary cirrhosis, primary sclerosing cholangitis and non-alcoholic fatty liver disease. Liver Int. 2009;29(7):1094-100.

17. Udaya M, Kabadi MD, Mary U, Kabadi RN, Premachandra BN. Low serum T3 and raised reverse T3 levels in hepatic cirrhosis: role of glucagon. Am J Gastroenterol. 1991;86(10):1504-7.

18. Van Thiel D, Gavaler JS, Tarter R, Schade RR, Gavaler JS, Sanghvi A. Pituitary and thyroid hormone levels before and after orthotopic hepatic transplantation and their responses to thyrotropin-releasing hormone. J Clin Endocrinol Metab. 1985;60(3):569-74.

19. Van Thiel DH, Udani M, Schade R, Sanghvi, A, Starzl., TE. Prognostic Value of Thyroid Hormone Levels in Patients Evaluated for Liver Transplantation. Hepatology. 1985;5(5):862-6. 